\section{Postestablishment Landscape Performance of Florida Native and Exotic Shrubs Under Irrigated and Nonirrigated Conditions}

\author{
S.M. Scheiber ${ }^{1,5,9}$, E.F. Gilman ${ }^{2,6}$, D.R. Sandrock ${ }^{3,5}$, M. Paz $^{2,7}$, \\ C. Wiese ${ }^{2,7}$, and Meghan M. Brennan ${ }^{4,8}$
}

ADDITIONAL INDEX wORDs. water management, maintenance, Callicarpa americana, Chionanthus virginicus, Ilex glabra, Ilex vomitoria 'Nana', Itea virginica, Myrica cerifera, Prunus angustifolia, Sevenoa repens, Viburnum obovatum, Zamia floridana, Duranta evecta, Gardenia augusta, Lagerstroemia indica, Ligustrum japonicum, Loropetalum chinensis, Nerium oleander, Pittosporum tobira, Rbaphiolepis indica, Viburnum odoratissimum, Viburnum suspensum

SuMMARY. Although new and innovative measures to reduce landscape water consumption are being sought, traditional methods of water restrictions and plant selection prevail. Species native to North America are often promoted as drought tolerant with little information to support or refute such claims. Furthermore, species performance is unknown in maintained environments such as commercial and residential landscapes. Thus, 10 native and 10 exotic species, commonly used in landscapes, were evaluated independently for postestablishment growth and aesthetics under irrigated and nonirrigated landscape conditions. Growth indices were recorded monthly, with dieback and plant density evaluated at termination of the experiment. At termination of the experiment, canopy size of eight native [beautyberry (Callicarpa americana), fringe tree (Chionanthus virginicus), yaupon holly (Ilex vomitoria 'Nana'), virginia sweetspire (Itea virginica), wax myrtle (Myrica cerifera), chickasaw plum (Prunus angustifolia), saw palmetto (Serenoa repens), and coontie (Zamia flovidana)] and eight exotic [golden dewdrop (Duranta evecta), cape jasmine (Gardenia augusta), crape myrtle (Lagerstroemia indica), oleander (Nerium oleander), japanese pittosporum (Pittosporum tobiva), indian hawthorn (Rbapbiolepis indica), sweet viburnum (Viburnum odoratissimum), and sandankwa viburnum ( $V$. suspensum) ] species were similar for irrigated and nonirrigated treatments. Irrigation resulted in larger canopy sizes for two native [walter's viburnum (V. obovatum) and inkberry (I. glabva)] and two nonnative [japanese privet (Ligustrum japonicum) and fringe flower (Loropetalum chinensis)] species. Among the native species with larger canopy sizes under irrigated conditions, all are indigenous to swamps and streams. With the exception of virginia sweetspire, plant density and dieback were similar for irrigated and nonirrigated plants of all taxa examined. Irrigated virginia sweetspire plants had higher plant density and dieback ratings than nonirrigated plants. Results indicate that, aesthetically, irrigated and nonirrigated plants were similar. Data emphasize the importance of selecting plant material adapted to existing environmental landscape conditions.

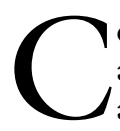
oncern among water management officials, researchers, and the public regarding landscape water consumption has escalated as demands on potable water supplies increase in Florida and other populated regions (Archer, 2002;
Beeson and Gilman, 1992; Salamone, 2002). Interested parties continually seek new and innovative measures to reduce consumption; however, traditional methods of water restriction and plant selection prevail. Restrictions in Florida vary depending on location, generally permitting 30 to $60 \mathrm{~d}$ of daily irrigation for landscape establishment and weekly to biweekly applications for the postestablishment phase (Bodle, 2001; Florida Department of State, 2007). Established landscapes can be maintained with minimal supplemental irrigation if plant selection is appropriate for site conditions (Sachs et al., 1975).

When choosing landscape plant material, native species are promoted as drought tolerant by everyone from the popular media to university professionals (Bodle, 2001; Haehle, 2004; Hostetler et al., 2003). Although many taxa are classified as drought resistant, these classifications often are based upon anecdotal observations of plant performance in landscape plantings (Garcia-Navarro et al., 2004; Levitt et al., 1995). Direct comparisons among native and introduced species using physiological measures are limited to support or refute such recommendations.

Garcia-Navarro et al. (2004) found mixed results evaluating relative water use among two native [vine hill manzanita (Arctostaphylos densiflora) and texas sage (Leucophyllum frutescens)] and two introduced [vanhoutte spirea (Spiraea vanbouteii) and laurustinus (Viburnum tinus)] species with neither native nor nonnative outperforming the other. Water use efficiency (WUE) increased as irrigation frequency increased, yet shoot and root dry weight were unaffected for nonnative red bird-of-paradise (Caesalpinia pulcherrima). In comparison, WUE declined and growth increased with increased frequency for native blue pale verde (Cercidium floridum) (Stabler and Martin, 2000). Zollinger et al. (2006) evaluated three

${ }^{3}$ Oregon State University, Department of Horticulture, $4151 \mathrm{Ag}$ and Life Sciences Building, Corvallis, OR 9733

${ }^{4}$ University of Florida, IFAS, College of Agriculture and Life Sciences, McCarty Hall, Gainesville, FL 32611

${ }^{5}$ Assistant Professor

${ }^{6}$ Professor.

${ }^{7}$ Biological Scientist.

${ }^{8}$ Coordinator, Statistical Research.

${ }^{9}$ Corresponding author. E-mail: scheiber@ufl.edu.

\begin{tabular}{llll}
\hline $\begin{array}{l}\text { Units } \\
\begin{array}{l}\text { To convert U.S. to SI, } \\
\text { multiply by }\end{array}\end{array}$ & U.S. unit & SI unit & $\begin{array}{l}\text { To convert SI to U.S., } \\
\text { multiply by }\end{array}$ \\
\hline 0.3048 & $\mathrm{ft}$ & $\mathrm{m}$ & 3.2808 \\
0.0283 & $\mathrm{ft}^{3}$ & $\mathrm{~m}^{3}$ & 35.3147 \\
3.7854 & $\mathrm{gal}$ & $\mathrm{L}$ & 0.2642 \\
2.54 & inch $(\mathrm{es})$ & $\mathrm{cm}$ & 0.3937 \\
48.8243 & $\mathrm{lb} / 1000 \mathrm{ft}^{2}$ & $\mathrm{~kg} \cdot \mathrm{ha}^{-1}$ & 0.0205 \\
28.3495 & $\mathrm{oz}$ & $\mathrm{g}$ & 0.0353
\end{tabular}

Hortechnology · January-March 2008 18(1) 
native and three introduced herbaceous perennials for growth and aesthetic quality in response to irrigation frequency. In general, shoot or root dry weight declined with decreased frequency for all taxa except 'Rondo Mix' penstemon (Penstemon barbatus var. praecox nanus rondo), a native species. Furthermore, visual quality was ranked highest on 'Rondo Mix' penstemon under water-limited conditions. Several studies comparing WUE or growth among grass species yielded similar results. Glenn et al. (1998) reported similar WUE among native and introduced species, but Blicker et al. (2003) found greater growth for native species. Bodle (2001), Haehle (2004), and Hostetler et al. (2003) suggest that native species should outperform introduced species in their native habitat. However, species performance is unknown in maintained environments such as commercial and residential landscapes (Anella, 2000; Knox, 1990). The objective of this study was to evaluate postestablishment growth and aesthetic quality of commonly used native and exotic shrubs under irrigated and nonirrigated landscape conditions.

\section{Materials and methods}

Ten native Florida taxa (beautyberry, fringe tree, inkberry, yaupon holly, virginia sweetspire, wax myrtle, chickasaw plum, saw palmetto, walter's viburnum, and coontie) and 10 nonnative taxa (golden dewdrop, cape jasmine, crape myrtle, japanese privet, fringe flower, oleander, japanese pittosporum, indian hawthorn, sweet viburnum, and sandankwa viburnum) were obtained from a commercial nursery in no. 1 or no. 2 containers. To be classified as a native Florida plant, the species it must have included Florida in its natural range at the time of European contact (1500 $\mathrm{CE})$ as defined by the Florida Exotic Pest Plant Council (2007). An exotic species is defined as a species introduced to Florida, purposefully or accidentally, from a natural range outside of Florida. Species were selected by referring to a commercial plant locator (Betrock Information Services, 2004). The 10 native and 10 exotic species most commonly grown in the nursery industry were chosen by counting the number of growers supplying plants; plants in both groups with the most growers were chosen for the study.

Taxa were planted on 23 Feb. 2005 into a field plot (U.S. Department of Agriculture hardiness zone $8 \mathrm{~b}$ ) of fine sand (Arredondo sand series) at the University of Florida Plant Science Research and Education Unit in Citra. Before transplant, rootbound materials were roughened by hand. Plants were installed with the top of the root ball at or slightly higher than the surrounding landscape soil. Plants were arranged on 5.4 - $\mathrm{ft}$ centers within rows and $16 \mathrm{ft}$ between rows in 3 -ft-wide strips and mulched with 3 - to 4 -inch pine bark nuggets to a depth of 3 inches (Florida Potting Soil, Orlando, FL). Weeds were eliminated from bed areas by hand pulling and treatment with glyphosate and hand pulling. Space between rows was maintained as bahiagrass (Paspalum notatum) strips and mowed regularly.

Each plant was irrigated with one bubbler emitter (Shrubbler $360^{\circ}$ Antelco, Longwood, FL) positioned on the root ball and mounted 4 inches above ground level. The Christiansen coefficient of uniformity was a minimum of 0.99 before planting (Haman et al., 2005). Irrigation was controlled using an automated irrigation time clock (Sterling 12; Superior Controls Co., Valencia, CA). Irrigation began at $0500 \mathrm{HR}$ and was completed by 0600 HR each day plants were irrigated. For $17 \mathrm{~d}$ after transplant (DAT), each plant received $3 \mathrm{~L}$ irrigation. At 18 DAT, irrigation was reduced to $3 \mathrm{~L}$ every $2 \mathrm{~d}$. On $26 \mathrm{Apr}$. 2005 , irrigation was reduced to $3 \mathrm{~L}$ applied once weekly for 10 replicates per species; irrigation was ended on the other 10 replicates.

Nutrition on each plot was managed with best management practices (Trenholm et al., 2002). Controlledrelease fertilizer was broadcast uniformly to a 2 -ft-diameter ring around each plant on 23 Mar. 2005 and again on 23 June 2005 at a standard rate of $1.5 \mathrm{lb} / 1000 \mathrm{ft}^{2} \mathrm{~N}$ of $17 \mathrm{~N}-$ 1.3P-9.1K (Professional Landscape and Ornamental Fertilizer; LESCO, Sebring, FL). This amounted to 12.5 $\mathrm{g}$ fertilizer/plant per application.

Climatic data. Daily climatic data were obtained from the Florida Automated Weather Station (FAWN) located $50 \mathrm{~m}$ from the site.
Growth INDICES. Measurements of tallest canopy height, widest canopy width (width 1 ), and width perpendicular to the widest width (width 2) were recorded to calculate growth indices (growth index $=$ height $\times$ width $1 \times$ width 2 ). During year $l$ of the experiment, all plants were measured immediately after transplant then monthly until 28 Oct. 2005. Plants were measured bimonthly during year 2 beginning on $27 \mathrm{Feb} .2006$ until termination of the experiment on 13 Sept. 2006. Flowers and fruits of the plant were not measured, nor were suckers from the root system or dead branches.

Aesthetic Quality. Plant density and canopy dieback were rated independently at termination of the experiment. Both parameters were rated on a scale of 1 point (dead) to 9 points (mounded, proportional form; dense; complete coverage, no dieback). Density evaluated the canopy fullness and dieback evaluated terminal branch death.

Data analysis. The experiment was planted and data analyzed as a randomized complete block design with 10 blocks of single-plant replicates. Each block contained all 20 species and both irrigation regime combinations for a total of 40 plants per block. Each species was analyzed separately. Because of reduced canopy volumes at the onset of year 2 resulting from winter damage and leaf senescence, data were analyzed separately by year. Regression equations were calculated for growth indices over time at each irrigation rate for each species for comparison of canopy size between irrigated and nonirrigated plants of each taxon. When all equations within a comparison were linear, slopes were compared using single-df contrast, and intercepts were analyzed as suggested by Snedecor and Cochran (1980). For growth indices, when at least one of the regression lines was nonlinear, data were analyzed further by PROC MIXED by species (Littell et al., 2006). When significant differences were indicated, mean separation was by Fisher's protected LSD (Snedecor and Cochran, 1980). Plant density and dieback were analyzed by NPARIWAY Wilcoxon. When differences in landscape quality were indicated, means separation was by Wilcoxon two-sample test (Howell, 2004). All analyses were conducted 
using SAS (version 9.1.3; SAS Institute, Cary, NC).

\section{Results and discussion}

Growth. Growth of irrigated and nonirrigated plants increased linearly over time $(P<0.0001)$ for four of the 20 species examined (crape myrtle, japanese pittosporum, indian hawthorn, and sandankwa viburnum, all exotic) in both years 1 (Fig. lC, $\mathrm{G}, \mathrm{H}, \mathrm{J}$ ) and 2 (Fig. 2C, G, H, J). Growth rate for both years was similar between irrigation regimes for each of these four species, indicating no response to irrigation. For 15 of the 16 remaining species, both irrigation regimes increased canopy size quadratically during year $\mathrm{l}(P<0.05$; Figs. IA, B, D-F, I; 3A, C, D, F-I) with the exception of nonirrigated virginia sweetspire (Fig. 3E), which increased linearly $(P<0.0001)$. Nonirrigated fringe tree also increased linearly whereas irrigated fringe tree decreased quadratically (Fig. 3B). With the exception of nonirrigated fringe tree (Fig. 4B), growth trends in year 2 (Figs. 2A, B, D-F, 2I; 4A, C-I) were similar to year 1 . Neither linear nor quadratic trends could be identified $(P>0.05)$ for either irrigated or nonirrigated coontie (Fig. 3J) during year 1 , which may be attributable to its unique growth habit. Coontie produces one to several flushes of fernlike leaves in a growing season. Ultimately the leaves arch downward to form a mound. Depending on the growth stage and corresponding measurement date, leaves may be either in an arching or upright position, thus potentially distorting canopy size (Scheper, 2007). Both irrigated and nonirrigated plants increased quadratically in year 2 (Fig. 4J).

Among the 15 species with quadratic growth trends in year 1 , canopy size of five native species (beautyberry, fringe tree, yaupon, chickasaw plum, and saw palmetto; Fig. 3A, B, D, G, $\mathrm{H}$ respectively) and three introduced species (golden dewdrop, cape jasmine, and oleander; Fig. 1A, B, F respectively) were affected $(P<$ 0.0001 ) solely by months after transplant (MAT). In other words, in year l size increased with time, but size was unaffected by irrigation $(P>0.05)$. During year 1 , canopy size of the native species inkberry was impacted by both irrigation regime and MAT (Fig. 3C). Final canopy size of irrigated inkberry was $41 \%$ larger than nonirrigated plants, and growth increased over time $(P<0.05)$. By year 2,12 species were affected solely by MAT, including the same eight affected in year 1 (Figs. 2A, B, F; 4A, $B, D, G, H)$ plus three additional native species (virginia sweetspire, wax myrtle, coontie; Fig. 4E, F, J) and the nonnative sweet viburnum (Fig. 2I). Although canopy size of virginia sweetspire (Fig. 4E) was initially larger among irrigated plants, by termination of the experiment growth was similar $(P>0.05)$ between irrigation regimes, suggesting an interaction. However, the interaction was nonsignificant $(P>0.05)$.

Irrigation regime and MAT affected canopy size of walter's viburnum (Fig. $4 \mathrm{H}$ ), japanese privet (Fig. 2D), and fringe flower (Fig. 2E) in year 2 with $29 \%, 52 \%$, and $45 \%$ increases respectively in canopy size among irrigated species.

An irrigation regime $\times$ MAT interaction occurred for three native and three nonnative species in year 1 , showing that the growth-enhancing effect of irrigation increased with time $(P<0.01)$. Canopy sizes of the natives virginia sweetspire (Fig. 3E), walter's viburnum (Fig. 3I), and wax myrtle (Fig. 3F), and the nonnatives fringe flower (Fig. IE), japanese privet (Fig. ID), and sweet viburnum (Fig. II) were 1.8-, 1.9-, 1.5-, 1.6-, 1.8-, and 1.4-fold greater respectively than nonirrigated counterparts. By the end of year 2 , only inkberry (Fig. 4C) had an irrigation regime $\times$ MAT interaction. Similar to year 1 , inkberry was affected by irrigation, but only during the last half of the year, with irrigated plants $86 \%$ larger than nonirrigated plants.

Although irrigation treatments were imposed at 2 MAT, growth differences did not become noticeable on any species except inkberry until 5 to 7 MAT. Lack of irrigation response might be explained partially by frequent rainfall between 8 weeks after transplant (WAT) and 20 WAT ( 2 and 5 MAT; Fig. 5). There were eight weekly precipitation totals in excess of 1 inch between 8 and 20 WAT. Between 24 and 36 WAT (6 and 9 MAT), precipitation totals more than 1 inch were recorded only four times, with two events occurring between 32 and 33 WAT (9 MAT). Data indicate that precipitation during the first 12 weeks ( 3 months) after treatment initiation compensated for elimination of supplemental irrigation.

Urban landscapes are characterized by reduced tree canopies resulting from development, varying nutrient levels resulting from human inputs, supplemental irrigation, soil compaction, nonuniform soils, and so forth (Harris et al., 2004; Knox, 1990), and adaptability to site conditions is species dependent. During year 1 of the current study, canopy sizes of three exotic (japanese privet, fringe flower, and sweet viburnum; Fig. 1D, E, I) and four native (inkberry, virginia sweetspire, wax myrtle and walter's viburnum; Fig. 3C, E, F, I) species were larger for irrigated plants than for nonirrigated plants. Among the four native species, all are indigenous to swamps and streams (Scheper, 2007; U.S. Department of Agriculture, 2006). By year 2, the number of irrigated species with larger canopies declined to one native (walter's viburnum; Fig. 4H) and two nonnatives (japanese privet and fringe flower; Fig. 2D, E). Growth increases in response to irrigation regimes have been documented for a number of tree and shrub species (Devitt et al., 1994, 1995; Gilman et al., 1996) and can differ depending on year after planting and stage of growth. Scheiber et al. (2007) reported canopy size and dry weight production of sweet viburnum increased in response to increased irrigation frequency in landscape conditions during establishment.

Canopy density and dieback were similar $(P<0.05)$ between irrigated and nonirrigated plants for all taxa examined, with the exception of virginia sweetspire (data not shown). Dieback was greater for nonirrigated than irrigated sweetspire $(P>0.05)$. Results indicate that both native and nonnative species can survive, grow, and maintain aesthetically acceptable quality (i.e., canopy density and dieback) in urban landscapes provided species are matched with the environmental conditions.

Although we found no evidence that commonly planted exotic shrub species grew better than species native to North America, several studies demonstrated the competitive advantages of exotic species in disturbed environments in response to environmental factors. Others report no 

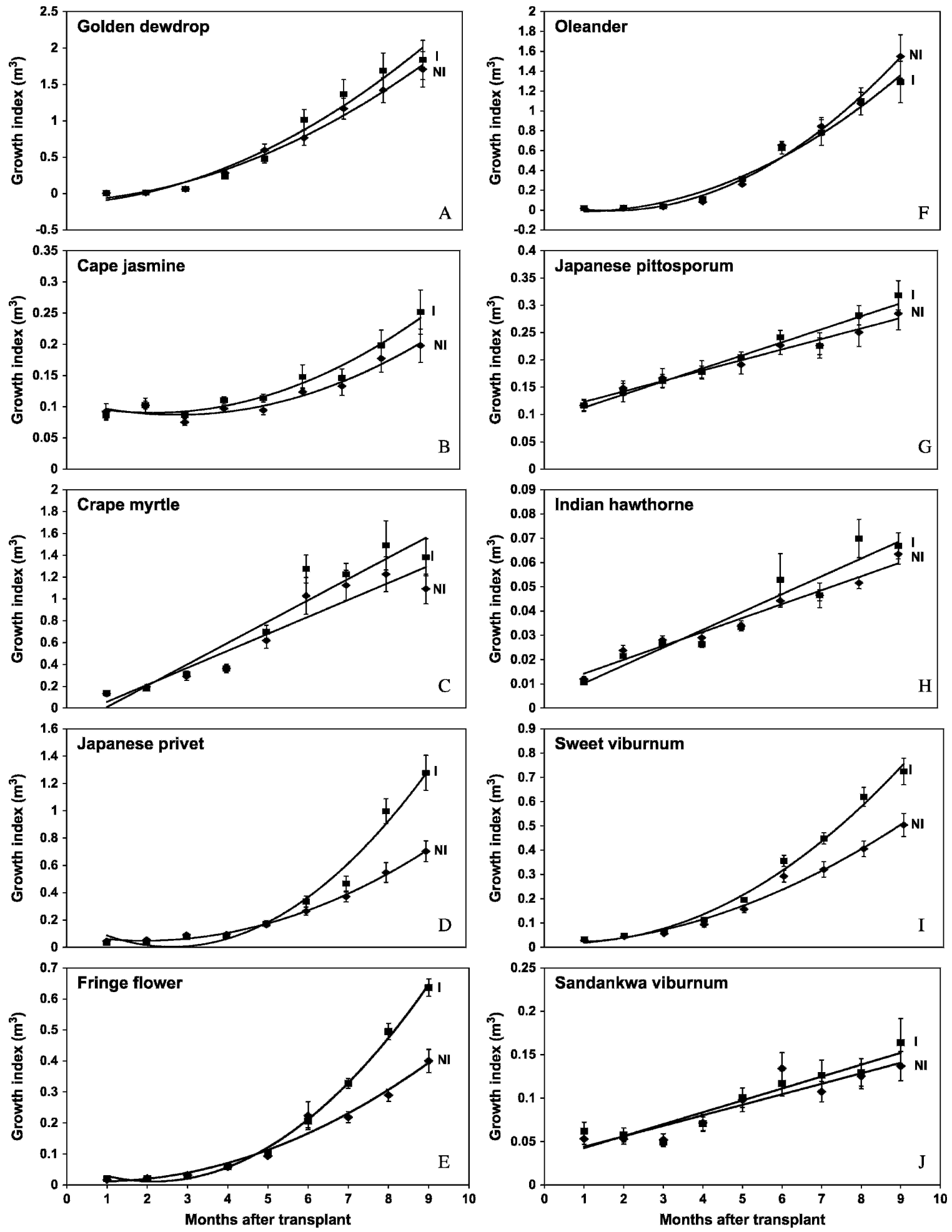

Fig. 1. Mean growth indices for nonnative species receiving either irrigation ( $\square)$ at $3 \mathrm{~L}(0.8$ gal)/irrigation event or no irrigation $(\diamond)$ from 1 month after transplant (MAT) through 9 MAT (year 1). (A) golden dewdrop, $(\square) \mathrm{y}=0.023 \mathrm{x}^{2}+0.0322 \mathrm{x}-0.1454$, $R^{2}=0.97 ;(\diamond) \mathrm{y}=0.0199 \mathrm{x}^{2}+0.0297 \mathrm{x}-0.1105, R^{2}=0.99$. (B) cape jasmine, $(\square) \mathrm{y}=0.0033 \mathrm{x}^{2}-0.0144 \mathrm{x}+0.1062, R^{2}=0.96$; $(\diamond) \mathrm{y}=0.003 \mathrm{x}^{2}-0.0168 \mathrm{x}+0.1106, R^{2}=0.96$. (C) crape myrtle, (四) y $=0.1941 \mathrm{x}-0.1857, v^{2}=0.91 ;(\diamond) \mathrm{y}=0.1543 \mathrm{x}-0.0969$, $v^{2}=0.91$. (D) japanese privet, $(\square) \mathrm{y}=0.0314 \mathrm{x}^{2}-0.1657 \mathrm{x}+0.2219, R^{2}=0.98 ;(\diamond) \mathrm{y}=0.0132 \mathrm{x}^{2}-0.0511 \mathrm{x}+0.0984, R^{2}=1.00$. (E) fringe flower, ( $(\nabla) \mathrm{y}=0.0135 \mathrm{x}^{2}-0.0583 \mathrm{x}+0.0738, R^{2}=1.00 ;(\diamond) \mathrm{y}=0.0056 \mathrm{x}^{2}-0.0083 \mathrm{x}+0.014, R^{2}=0.97$. $(\mathrm{F})$ oleander, (घ) $\mathrm{y}=0.0207 \mathrm{x}^{2}-0.0356 \mathrm{x}-6 \mathrm{E}-05, R^{2}=0.99 ;(\diamond) \mathrm{y}=0.0289 \mathrm{x}^{2}-0.0975 \mathrm{x}+0.0763, R^{2}=0.99$. (G) japanese pittosporum, (匹) $\mathrm{y}=0.0237 \mathrm{x}+0.089, r^{2}=0.96 ;(\diamond) \mathrm{y}=0.0191 \mathrm{x}+0.1039, r^{2}=0.98$. (H) indian hawthorn, $(\square) \mathrm{y}=0.0073 \mathrm{x}+0.0029, r^{2}=$ $0.93 ;(\diamond) \mathrm{y}=0.0057 \mathrm{x}+0.0085, v^{2}=0.97$. (I) sweet viburnum, $(\square) \mathrm{y}=0.0107 \mathrm{x}^{2}-0.0154 \mathrm{x}+0.028, R^{2}=0.99 ;(\diamond) \mathrm{y}=0.0058 \mathrm{x}^{2}+$ $0.0037 \mathrm{x}+0.0091, R^{2}=0.98$. (J) sandankwa viburnum, $(\square) \mathrm{y}=0.0137 \mathrm{x}+0.0288, r^{2}=0.90 ;(\diamond) \mathrm{y}=0.0121 \mathrm{x}+0.0319, v^{2}=0.86$. Treatments were initiated 2 MAT in Citra, FL. Each point represents the means with \pm SE indicated by bars. $1 \mathrm{~m}^{3}=35.3147 \mathrm{ft}^{3}$. 

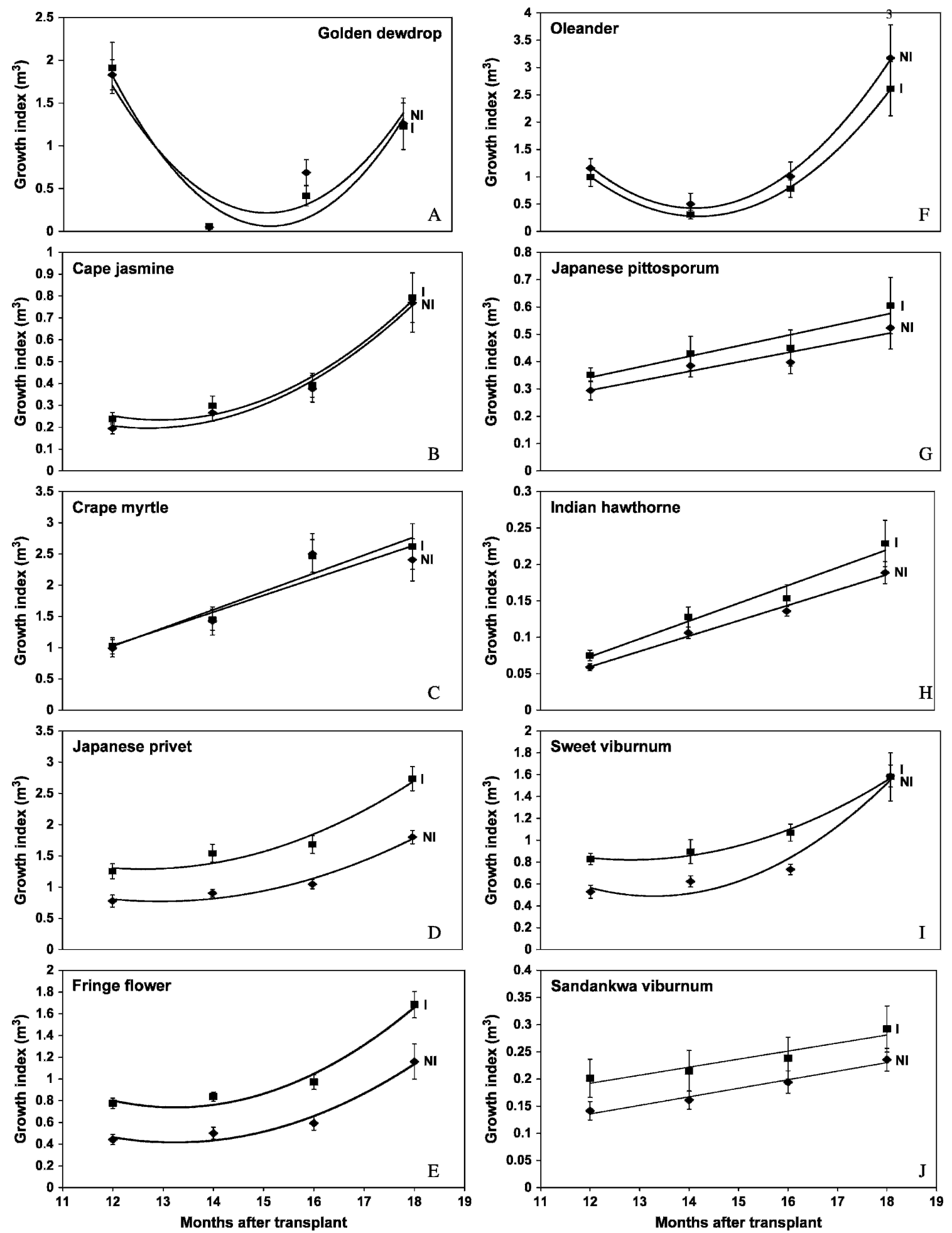

Fig. 2. Mean growth indices for nonnative species receiving either irrigation $(-)$ at $3 \mathrm{~L}(0.8 \mathrm{gal}) /$ per irrigation event or no irrigation

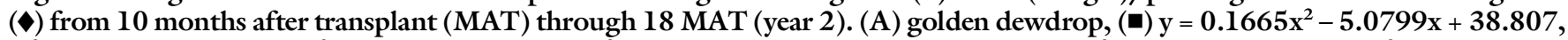
$R^{2}=0.93 ;(\diamond) \mathrm{y}=0.1471 \mathrm{x}^{2}-4.4673 \mathrm{x}+34.129, R^{2}=0.82$. (B) cape jasmine, $(\square) \mathrm{y}=0.0214 \mathrm{x}^{2}-0.5529 \mathrm{x}+3.8117, R^{2}=0.98 ;(\diamond) \mathrm{y}=$ $0.0201 \mathrm{x}^{2}-0.5109 \mathrm{x}+3.4435, R^{2}=0.99$. (C) crape myrtle, (-) $\mathrm{y}=0.2899 \mathrm{x}-2.457, v^{2}=0.93 ;(\diamond) \mathrm{y}=0.2661 \mathrm{x}-2.1608, v^{2}=0.86$ (D) japanese privet, (ש) $\mathrm{y}=0.048 \mathrm{x}^{2}-1.2109 \mathrm{x}+8.9259, R^{2}=0.96 ;(\bullet) \mathrm{y}=0.0393 \mathrm{x}^{2}-1.0182 \mathrm{x}+7.3668, R^{2}=0.97$. (E) fringe flower, ( $(\square) \mathrm{y}=0.0407 \mathrm{x}^{2}-1.0787 \mathrm{x}+7.8824, R^{2}=0.98 ;(\checkmark) \mathrm{y}=0.0318 \mathrm{x}^{2}-0.8406 \mathrm{x}+5.9781, R^{2}=0.97$. (F) oleander, $(\varpi) \mathrm{y}=0.1677 \mathrm{x}^{2}-4.7175 \mathrm{x}+33.48, R^{2}=1.00 ;(\diamond) \mathrm{y}=0.1763 \mathrm{x}^{2}-4.9621 \mathrm{x}+35.34, R^{2}=1.00$. (G) japanese pittosporum, (๑) $\mathrm{y}=$ $0.039 \mathrm{x}-0.1255, v^{2}=0.90 ;(\diamond) \mathrm{y}=0.035 \mathrm{x}-0.1246, v^{2}=0.92$. (H) indian hawthorn, (-) $\mathrm{y}=0.0243 \mathrm{x}-0.2186, v^{2}=0.97 ;(\diamond) \mathrm{y}=$ $0.0209 \mathrm{x}-0.1918, v^{2}=0.99$. (I) sweet viburnum, (ब) $\mathrm{y}=0.0276 \mathrm{x}^{2}-0.7076 \mathrm{x}+5.3505, R^{2}=0.99 ;(\diamond) \mathrm{y}=0.0474 \mathrm{x}^{2}-1.2589 \mathrm{x}+$ 8.8405, $R^{2}=0.96$. (J) sandankwa viburnum; $(\square) \mathrm{y}=0.0148 \mathrm{x}+0.0148, v^{2}=0.91 ;(\diamond) \mathrm{y}=0.0158 \mathrm{x}-0.0533, v^{2}=0.98$.

Treatments were initiated 2 MAT in Citra, FL. Each point represents the means with \pm SE indicated by bars. $1 \mathrm{~m}^{3}=35.3147 \mathrm{ft}^{3}$. 

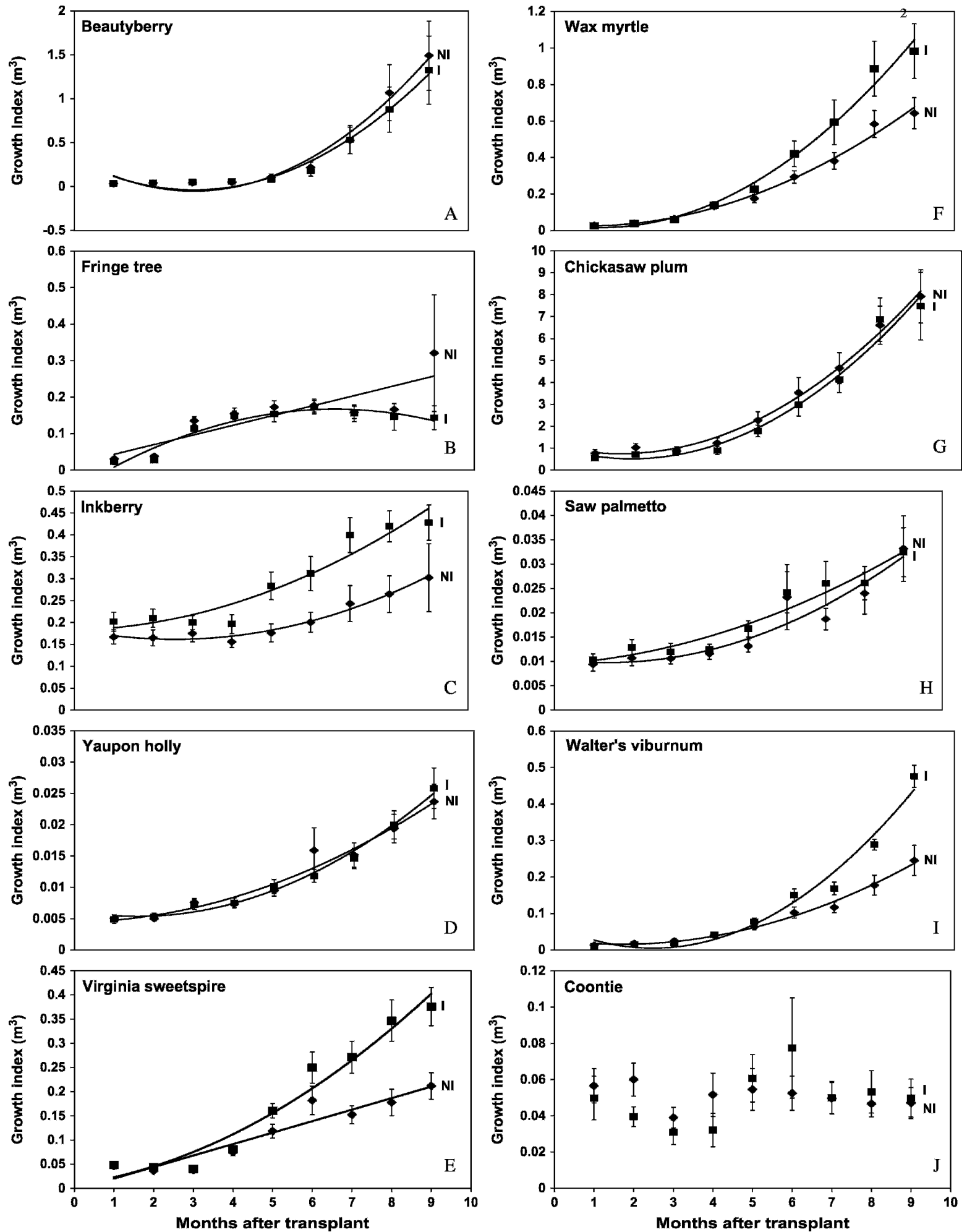

Fig. 3. Mean growth indices for nonnative species receiving either irrigation $(\square)$ at $3 \mathrm{~L}(0.8$ gal $)$ /irrigation event or no irrigation $(\diamond)$ from 1 month after transplant (MAT) through 9 MAT (year 1). (A) beautyberry, $(\square) \mathrm{y}=0.0371 \mathrm{x}^{2}-0.225 \mathrm{x}+0.3035, R^{2}=$ $0.98 ;(\diamond) \mathrm{y}=0.0424 \mathrm{x}^{2}-0.2568 \mathrm{x}+0.3369, R^{2}=0.98$. (B) fringe tree, $(\square) \mathrm{y}=-0.0052 \mathrm{x}^{2}+0.0679 \mathrm{x}-0.0538, R^{2}=0.92 ;(\diamond) \mathrm{y}=$ $0.0268 \mathrm{x}+0.0163, v^{2}=0.75$. (C) inkberry, $(\square) \mathrm{y}=0.0032 \mathrm{x}^{2}+0.0023 \mathrm{x}+0.1822, R^{2}=0.92 ;(\diamond) \mathrm{y}=0.0035 \mathrm{x}^{2}-0.0178 \mathrm{x}+$

$0.1843, R^{2}=0.97$. (D) yaupon holly, ( $(\square) \mathrm{y}=0.0004 \mathrm{x}^{2}-0.0011 \mathrm{x}+0.0063, R^{2}=0.99 ;(\diamond) \mathrm{y}=0.0002 \mathrm{x}^{2}+9 \mathrm{E}-05 \mathrm{x}+0.0045, R^{2}=$ 0.97. (E) virginia sweetspire, $(\square) \mathrm{y}=0.0036 \mathrm{x}^{2}+0.0119 \mathrm{x}+0.0075, R^{2}=0.96 ;(\diamond) \mathrm{y}=0.0237 \mathrm{x}-0.0034, r^{2}=0.90$. (F) wax myrtle, $(\square) \mathrm{y}=0.0168 \mathrm{x}^{2}-0.0391 \mathrm{x}+0.039, R^{2}=0.99 ;(\diamond) \mathrm{y}=0.0096 \mathrm{x}^{2}-0.015 \mathrm{x}+0.0307, R^{2}=0.99$. (G) chickasaw plum, ( $(\square) \mathrm{y}$ $=0.1475 \mathrm{x}^{2}-0.5606 \mathrm{x}+1.0485, R^{2}=0.98 ;(\diamond) \mathrm{y}=0.1364 \mathrm{x}^{2}-0.444 \mathrm{x}+1.1104, R^{2}=0.9935$. (H) saw palmetto, ( $(\square) \mathrm{y}=0.0002 \mathrm{x}^{2}$ $+0.0005 \mathrm{x}+0.0094, R^{2}=0.94 ;(\diamond) \mathrm{y}=0.0004 \mathrm{x}^{2}-0.001 \mathrm{x}+0.0105, R^{2}=0.91$. (I) walter's viburnum, $(\square) \mathrm{y}=0.0102 \mathrm{x}^{2}-$ $0.0503 x+0.0673, R^{2}=0.97 ;(\diamond) y=0.0041 x^{2}-0.0135 x+0.0267, R^{2}=0.99$. (J) coontie. Treatments were initiated 2 MAT in Citra, FL. Each point represents the means with \pm SE indicated by bars. $1 \mathrm{~m}^{3}=35.3147 \mathrm{ft}^{3}$. 

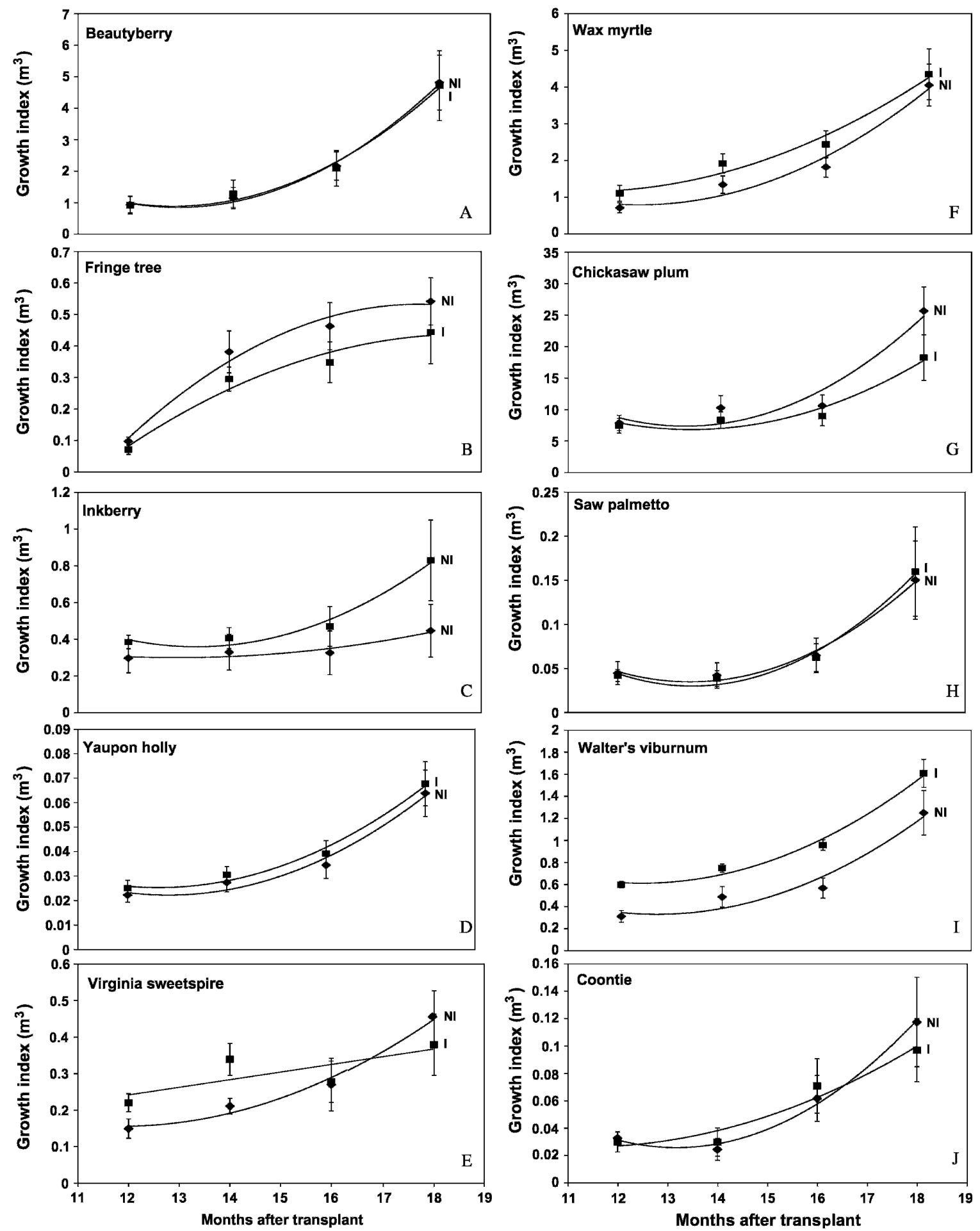

Fig. 4. Mean growth indices for nonnative species receiving either irrigation $(\varpi)$ at $3 \mathrm{~L}(0.8$ gal $)$ /irrigation event or no irrigation

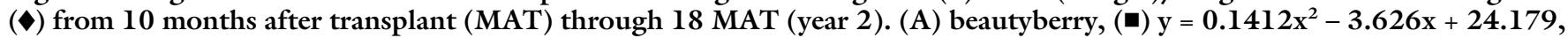
$R^{2}=0.99 ;(\diamond) \mathrm{y}=0.1528 \mathrm{x}^{2}-3.9512 \mathrm{x}+26.408, R^{2}=1.00$. (B) fringe tree, $(\square) \mathrm{y}=-0.008 \mathrm{x}^{2}+0.2976 \mathrm{x}-2.3415, R^{2}=0.97 ;(\diamond)$ $\mathrm{y}=-0.0128 \mathrm{x}^{2}+0.4555 \mathrm{x}-3.5121, R^{2}=0.98$. (C) inkberry, $(\cdot) \mathrm{y}=0.0268 \mathrm{x}^{2}-0.6966 \mathrm{x}+4.8936, R^{2}=1.00 ;(\diamond) \mathrm{y}=0.0063 \mathrm{x}^{2}-$ $0.1582 \mathrm{x}+1.29, R^{2}=0.98$. (D) yaupon holly, (D) $\mathrm{y}=0.0014 \mathrm{x}^{2}-0.0362 \mathrm{x}+0.2538, R^{2}=0.99 ;(\bullet) \mathrm{y}=0.0015 \mathrm{x}^{2}-0.0388 \mathrm{x}+$ $0.2707, R^{2}=0.98$. (E) virginia sweetspire, $(\cdot) \mathrm{y}=0.0208 \mathrm{x}-0.0084, v^{2}=0.59 ;(\diamond) \mathrm{y}=0.0078 \mathrm{x}^{2}-0.1843 \mathrm{x}+1.2482, R^{2}=0.98$. (F) wax myrtle, (匹) y =0.0686 $\mathrm{x}^{2}-1.547 \mathrm{x}+9.871, R^{2}=0.98 ;(\diamond) \mathrm{y}=0.1 \mathrm{x}^{2}-2.4757 \mathrm{x}+16.114, R^{2}=0.97$. (G) chickasaw plum, (-) y = 0.5235 $\mathrm{x}^{2}-14.052 \mathrm{x}+101.12, R^{2}=0.95 ;(\diamond) \mathrm{y}=0.7911 \mathrm{x}^{2}-21.047 \mathrm{x}+147.35, R^{2}=0.93$. (H) saw palmetto, (匹) $\mathrm{y}=0.0067 \mathrm{x}^{2}-0.1796 \mathrm{x}+1.2336, R^{2}=0.99 ;(\diamond) \mathrm{y}=0.0058 \mathrm{x}^{2}-0.1547 \mathrm{x}+1.0666, R^{2}=0.99$. (I) walter's viburnum, (匹) $\mathrm{y}=$ $0.0312 \mathrm{x}^{2}-0.7753 \mathrm{x}+5.4193, R^{2}=0.99 ;(\diamond) \mathrm{y}=0.0316 \mathrm{x}^{2}-0.8027 \mathrm{x}+5.4265, R^{2}=0.95$. (J) coontie, ( $(\square) \mathrm{y}=0.0016 \mathrm{x}^{2}-$ $0.0369 \mathrm{x}+0.2344, R^{2}=0.95 ;(\diamond) \mathrm{y}=0.004 \mathrm{x}^{2}-0.1055 \mathrm{x}+0.7209, R^{2}=0.99$. Treatments were initiated 2 MAT in Citra, FL. Each point represents the means with $\pm \mathrm{sE}$ indicated by bars. $1 \mathrm{~m}^{3}=35.3147 \mathrm{ft}^{3}$. 


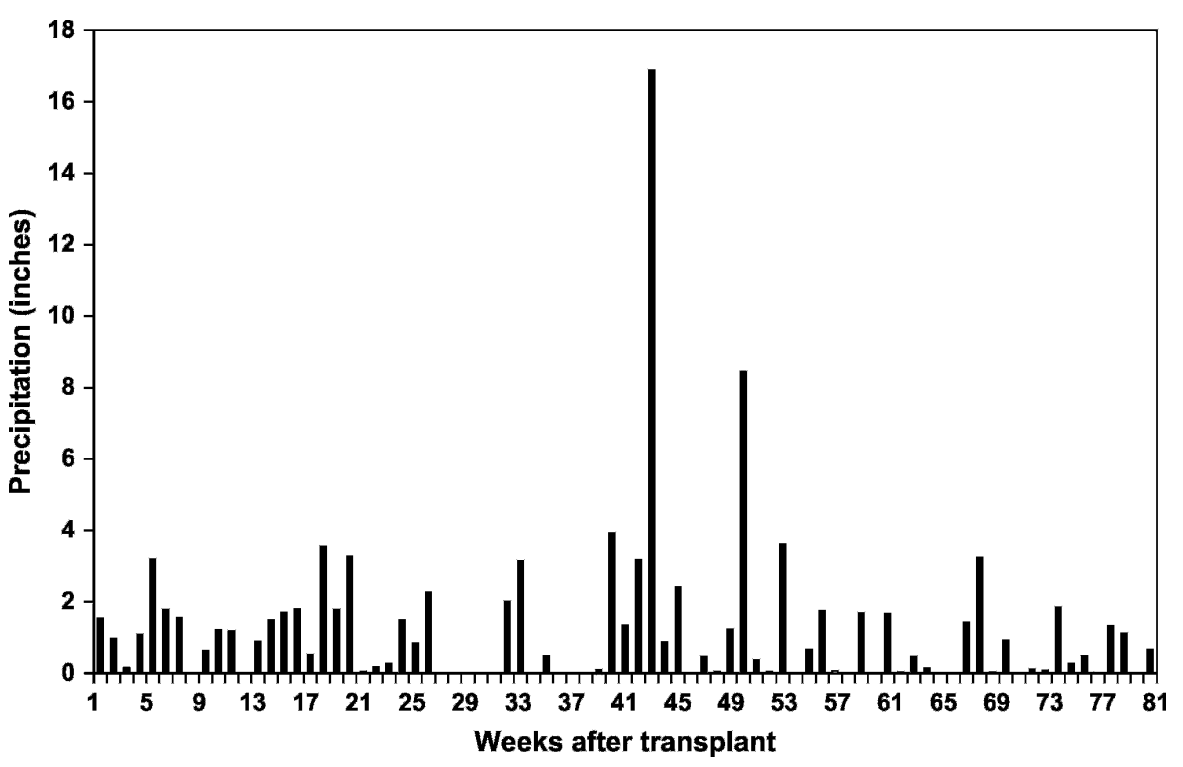

Fig. 5. Weekly precipitation totals in Citra, FL, for 23 Feb. 2005 through 13 Sept. 2006. 1 inch $=2.54 \mathrm{~cm}$.

differences between natives and nonnatives, indicating responses are species dependent. Sanford et al. (2002) compared three pairs of analogous native and exotic species in an open field site and an understory shade site. The exotic species, norway maple (Acer platanoides) and autumn olive (Eleagnus umbellate), had better survival than sugar maple (Acer saccharum) and silky dogwood (Cornus amomum) in both habitats after 2 years. Biomass was similar between habitats.

O'Dwyer and Attiwill (1999) found that under increasing concentrations of $\mathrm{P}$, the percent area covered by wallaby grass (Austrodanthonia spp.), the native dominant species, decreased and the percent covered by exotic weedy species increased. In contrast, Allcock (2002) found that high $\mathrm{P}$ levels did not increase the competitive abilities of the exotic species when grown with natives. Fogarty and Facelli (1999) found that soil taken from a site invaded by exotic english broom (Cytisus scoparius) had significantly higher $\mathrm{C}, \mathrm{N}$, and soluble $\mathrm{P}$ than soil from a comparable uninvaded site. Furthermore, english broom did outcompete native beaked hakea (Hakea rostrata) under high nutrient conditions. Leishman and Thomson (2005) examined the effects of increased nutrients on 28 plant species in four categories: native noninvasive, native invasive, exotic noninvasive, and exotic invasive.
Under greenhouse conditions, percent survival of exotic invasive species was higher than other plant categories when nutrients were increased. Biomass increased for all categories except native noninvasive. Clearly we have a great deal to learn about the habits and survival strategies of shrubs commonly used as landscape plants.

Despite many references classifying taxa as drought tolerant or drought resistant based on anecdotal data (Garcia-Navarro et al., 2004; Levitt et al., 1995), it must be emphasized that the results of this study were not intended to categorize the taxa as such because physiological measures of water stress are required for such classifications. The objective was to examine the effect site conditions (irrigated vs. nonirrigated) on growth and aesthetic quality of native and nonnative species. Data emphasize the importance of selecting plant material adapted to environmental conditions at the planting site. Although selection of native species to conserve water in urban landscapes has been recommended, performance in the landscape appears to be associated with factors other than native origin. Results provide valuable information to assist in the design of low-maintenance landscapes. Urban landscapes vary greatly from natural habitats, and proper plant selection, whether native or nonnative, promotes sustainability and can minimize supplemental inputs without compromising aesthetic appearance provided introduced species do not pose the threat of invasiveness.

\section{Literature cited}

Allcock, K.G. 2002. Effects of phosphorus on growth and competitive interactions of native and introduced species found in White Box woodlands. Austral Ecol. 27:638-646.

Anella, L. 2000. Debunking native myths. Amer. Nurseryman 192:39-43.

Archer, M. 2002. We must heed scary warnings about aquifer. Orlando Sentinel 17 Feb.:Al.

Beeson R.C., Jr. and E.F. Gilman. 1992. Diurnal water stress during landscape establishment of slash pine differs among three production methods. J. Arboriculture 18:281-286.

Betrock Information Services. 2004. Betrock's plantfinder. Betrock Information Services, Hollywood, FL.

Blicker, P.S., B.E. Olson, and J.M. Wraith. 2003. Water use and water-use efficiency of the invasive Centaurea maculos $a$ and three native grasses. Plant Soil 254:371-381.

Bodle, M. (ed.). 2001. Waterwise south Florida landscapes. Southwest Florida Water Management District, West Palm Beach, FL.

Devitt, D.A., R.L. Morris, and D.S. Neuman. 1994. Evapotranspiration and growth response of three woody ornamental species placed under varying irrigation regimes. J. Amer. Soc. Hort. Sci. 119:452-457.

Devitt, D.A., D.S. Neuman, D.C. Bowman, and R.L. Morris. 1995. Water use of landscape plants grown in an arid environment. J. Arboriculture 21:239-245.

Florida Department of State. 2007. 40D-22: Year-round water conservation measures. 5 Aug. 2007. <www.flrules. org/gateway/chapterhome .asp? chapter $=$ $40 \mathrm{D}-22>$.

Florida Exotic Plant Pest Council. 2007. Florida Exotic Plant Pest Council. 4 June 2007. <www.fleppc.org/>.

Fogarty, G. and J.M. Facelli. 1999. Growth and competition of Cytisus scoparius, an invasive shrub, and Australian native shrubs. Plant Ecol. 144:27-35.

Garcia-Navarro, M.C., R.Y. Evans, and R.S. Montserrat. 2004. Estimation of relative water use among ornamental landscape species. Sci. Hort. 99:163-174.

Gilman, E.F., T.H. Yeager, and D. Weigle. 1996. Fertilizer, irrigation, and root ball 
slicing affects burford holly growth after planting. J. Environ. Hort. 14:105-110.

Glenn, E., R. Tanner, S. Mendez, T. Kehret, D. Moore, J. Garcia, and C. Valdes. 1998. Growth rates, salt tolerance and water use characteristics of native and invasive riparian plants from the delta of the Colorado River, Mexico. J. Arid Environ. 40:281-294.

Haehle, R. 2004. Native Florida plants: Low maintenance landscaping and gardening. Taylor Trade Publishing, Lanham, MD.

Haman, D.Z., A.G. Smajstrla, and D.J. Pitts. 2005. Efficiencies of irrigation systems used in Florida nurseries. University of Florida Institute of Food and Agricultural Sciences Coop. Ext. Serv. Bul. 312.

Harris, R.W., J.R. Clark, and N.P. Matheny. 2004. Arboriculture: Integrated management of landscape trees, shrubs, and more. Prentice Hall, Upper Saddle River, NJ.

Hostetler, M., G. Klowden, S. Miller, and K. Youngentob. 2003. Landscaping backyards for wildlife: Top ten tips for success. University of Florida Institute of Food and Agricultural Sciences Electronic Data Information Source Publ. No. UW175.

Howell, D.C. 2004. Fundamental statistics for behavioral sciences. Thomson Wadsworth, Stamford, CT.
Knox, G. 1990. Landscape design for water conservation. University of Florida Institute of Food and Agricultural Sciences Electronic Data Info. Source Publ. No. ENH72.

Leishman, M.R. and V.P. Thomson. 2005. Experimental evidence for the effects of additional water nutrients and physical disturbance on invasive plants in low fertility Hawkesbury Sandstone soils, Sydney, Australia. J. Ecol. 93:38-49.

Levitt, D.G., J.R. Simpson, and J.L. Tipton. 1995. Water use of two landscape tree species in Tucson, Arizona. J. Amer. Soc. Hort. Sci. 120:409-416.

Littell, R.C., G.A. Milliken, W.W. Stroup, R.D. Wolfinger, and O. Schabenberger. 2006. SAS for mixed models. 2nd ed. SAS Institute Inc., Cary, NC.

O'Dwyer, C. and P.M. Attiwill. 1999. A comparative study of habitats of the golden sun moth Synemon plana Walker (Lepidoptera: Castniidae): Implications for restoration. Biol. Conserv. 89:131-141.

Sachs, R.M., T. Kretchun, and T. Mock. 1975. Minimum irrigation requirements for landscape plants. J. Amer. Soc. Hort. Sci. 100:499-502.

Salamone, D. 2002. A drying oasis series: Florida water crisis chapter 1. Orlando Sentinel 3 Mar.:Al.

Sanford, N.L., R.A. Harrington, and J.H. Fownes. 2002. Survival and growth of native and alien woody seedlings in open and understory environments. For. Ecol. Manage. 183:377-385.

Scheiber, S.M., E.F. Gilman, M. Paz, and K.A. Moore. 2007. Irrigation affects landscape establishment of burford holly, pittosporum, and sweet viburnum. HortScience 42:344-348.

Scheper, J. 2007. Floridata. 5 June 2007. $<$ www.floridata.com>.

Snedecor and Cochran. 1980. Statistical methods. 7th ed. Iowa State University Press, Ames, IA.

Stabler, L.B. and C.A. Martin. 2000. Irrigation regimes differentially affect growth and water use efficiency of two southwest landscape plants. J. Environ. Hort. 18:66-70.

Trenholm, L.E., E.F. Gilman, G.W. Knox, and R.J. Black. 2002. Fertilization and irrigation needs for Florida lawns and landscapes. University of Florida Institute of Food and Agricultural Sciences Electronic Data Info. Source Publ. No. ENH860.

U.S. Department of Agriculture. 2006. The PLANTS database. 25 Dec. 2006. $<$ http://plants.usda.gov/>.

Zollinger, N., R. Kjelgren, T. CernyKoenig, K. Kopp, and R. Koenig. 2006. Drought responses of six ornamental herbaceous perennials. Sci. Hort. 109: 267-274. 